the wood and a variety of exhibits illustrated work on this problem. The rate of flow of an inert gas under a fixed pressure is being used to determine the permeability of wood specimens in the three directions of the grain, and a technique has been developed which enables the process of impregnation under pressure to be studied photographically or by direct observation. A short film strikingly demonstrated the variation in the rato of penetration of liquids in different regions of a wood specimen.

While the common furniture beetle and the death. watch beetle are widely distributed throughout Britain, the house longhorn beetlo (Hylotrupes bajulus) causes serious damage only in and around Surrey, and in this area a large increase in damage has been noticed during the past twenty-five years. It was illustrated by moans of maps that this area coincides with that of the highest mean temperatures during the breeding months of this insect (June-September). It is of some interest that on experiment is being planned in collaboration with scientists in the four Scandinavian countries to explore in a controlled manner the effect of temperature and humidity on the activity of this insect.

Wood is used by a few industries on a very large scale and by very many smaller industries in small quantities but in a highly specialized manner. The range of problems still to be solved was well illustrated by the exhibits on show on this occasion.

E. J. Gibson

\title{
INTERNATIONAL HYDROGRAPHIC RESEARCH
}

$\mathrm{T}$ HE eighth International Hydrographic Conference opened in Monaco on May 8, under the presidency of Prince Rainier of Monaco. The opening address was delivered by Rear-Admiral Knox, president of the Directing Committee of the International Hydrographic Bureau, who welcomed dele. gates from forty-one countries, as well as observers from non-member countries and from international scientific and maritime organizations. $\mathrm{He}$ expressed gratitude for the generous contributions of data to the Bureau, especially those from the Academy of Sciences of the U.S.S.R. and the Woods Hole Oceanographic Institute of the United States. Another welcome gift came from Portugal-a complete set of the Cartographic Monument of Portugal from an Executive Commission appointed by the Portuguese Government commemorating the five-hundredth anniversary of the death of Prince Henry the Navi. gator.

The General Bathymetric Chart of the Oceans, which can be seen in the Musée Océanographique in Monaco, was the lifo-work of the late Prince Albert of Monaco, and thereforo is one of the reasons for the Headquarters being in Monaco. It is now proposed to complete and print the Chart in such a way as to satisfy the demands of hydrographic officers, oceanographers and others. In national hydrographic offices the bathymetric data is plotted to $1 / 1,000,000$; however, the General Bathymotric Chart of the Oceans is plotted to $1 / 10,000,000$. This has become a financial responsibility of the International Hydrographic Bureau, and it was decided that with co-operation of all State members and other interested agencies, the Chart would be compiled under the auspices of the Bureau.

It has become necessary to revise the statutes of the International Hydrographic Bureau and bring them into line with more forward-thinking policies. However, before this can be carried out, a decision must be taken concerning the Convention on Juridical Personality. At the conference held in 1957 action was started to gain juridical personality recognized, this being necessary before diplomatic status can be requested, as with other international bodies. After submission to Foreign Office Ministers, only fifteen signatures of State members wore obtained, which was insufficient, twenty-four signatures being required. It has now been decided to prepare a con. vention with a new text, and this will be drafted in Paris, preferably before tho end of the present year. One interesting and useful matter discussed was the setting up of working committees between the five-year conferences, when work could be set in motion in preparation for discussion at conferencelevel. Agreement was reached on the importance of studying, together with other bodies, a comprehensive system of classification for documentation covering, principally, hydrography, oceanography, geodesy and allied subjects, with the view of establishing a documentation service.

The question of agreement on the velocity to be adopted for all oceanic soundings using echo-sounding apparatus was thoroughly explored, as some standardization is desirable. It was agreed that machines be used 'preferably' calibrated for a sounding velocity 820 fathoms (1,500 metres) per second.

Progress towards the international adoption of the metric system is very slow, principally on account of the confusion it would cause to navigators of many countries, whose instruments are calibrated in fathoms, and soundings on charts are given in fathoms and feet. The International Hydrographic Bureau felt that as yet it is unable to take any effective action since hydrographic offices tend to conform to their national unit of measurement, and until general standardization at an international level has been reached little can be done. In the meantime, all countries will endeavour to work towards that goal and report progress every five years.

The importance of mean sea-levol in the choice of the geoid was the subject of a proposal that the Bureau should be responsible for determining the norms to be followed in the determination of mean sea-level with the ultimate object of standardization for future work of wider scope. As this does not fall within the field of hydrography, the Bureau felt that it was not competent to carry out the work. It was decided that this study should be transferred to the Permanent Service for Mean Sea Level for consideration and that State members be advised of their reply.

A proposal was carried which recommended that, in the terminology of lights in their national language, hydrographic offices adhero as closely as possible to the document entitled Nomenclature of Lights Used for Marine Navigation, drawn up by the International Association of Lighthouse Authorities in June 1960 and distributed to hydrographic offices by the Bureau.

An exhibition of recent instruments and equipment used in hydrography was prepared for the Conference, 
and revealed the great advances made in the field of electronics. H.M.S. Vidal arrived to assist in the demonstration of equipment, and Rear-Admiral Irving, hydrographer of tho Navy, headed the British delegation at the Conference. A 6-hr. cruise was made along the coast when the delegatos were given a practical demonstration of a 'Tellurometer' (Vickers) microwave system for use in hydrographic survey, where the master installation is on the ship with known base remote stations ashore. It is intended for round-the-clock operations and to save manpower. The automatic plotting table provides an automatic plot of the ship's position on a 24 -in. $\times$ 24-in. chart with an accuracy approaching 1 part in 10,000. An enterprising exhibitor chartered a launch for the duration of the Conference to demonstrate a highly accurate radio survey-accuracy position-fixing system. The 'Track Plotter' (Decca) provides a pictorial display of the vessel's movo. ments on a special chart; the position-line numbers can at the same time be read from easily defined sequential counters. The control operates regardless of visibility and the absence of conventional facilities.
A new development also demonstrated was a 'Towed Surveying Asdic' (Kelvin Hughes). This apparatus contains a transducor facing sideways, giving a fan-shaped beam-1 $1 \frac{1}{2}^{\circ}$ horizontal plane, $19^{\circ}$ vertical plane-of supersonic energy which scans as it is drawn along in the sea. The returning echoes make their imprint on an 18-in. wide chart, thus providing details of the sea bottom over a swathe $800 \mathrm{yd}$. wide when the depth may be only $30 \mathrm{yd}$.

As with all conferences, there is often a gay beam threading its way between the scientific intricacies. This was admirably demonstrated by one of the closing social events-a dinner given by the Monagasque Government. The president of the conference, Ingenieur Général Guggenheim, expressed on behalf of the participants of the conference appreciation of the warm welcome extended to them by the Principality of Monaco, where forty years ago the Bureau was founded. He pointed out the work of hydrographers is of an international character and not solely for hydrographic services. This aspect was foreseen even before the First World War, but did not materialize until the birth of the International Hydrographic Bureau.

Alice KeNNEDY

\section{THE INTERNATIONAL BIOLOGICAL PROGRAMME}

$\mathrm{D}$ URING May 21-22, at Morges, Switzerland, a programme of co-operative research in basic biology on an international scale was outlined by a Planning Committoe organized for this purpose by the International Council of Scientific Unions. Two years of preliminary discussions by members of the International Council and three of its affiliated Unions-the International Union of Biological Sciences, the International Union of Biochemistry and the International Union of Physiological Scienceshad convinced these scientists that there is a genuine need for such a programme. These discussions had further emphasized the fact that, although biologists might derive inspiration and encouragement from the success of the International Geophysical Year, a large-scale programme of intensive research, highly concentrated in a small period of time, is not practicable in the biological sciences. The scope of biology is so vast, and affects so many facets of human life. that it could not possibly be covered in a single co-ordinated effort. Consequently, the Committee appointed by the International Council of Scientific Unions docided not to attempt to organize a single International Biological Year comparable with the International Geophysical Year.

On the other hand, the biologists meeting at Morges, both during preliminary discussions and at the meeting itself, became increasingly aware of the need for an International Biological Programme of a somewhat different nature. This need arises from the fact that many problems of vital importance to man's future welfare can be solved only by means of new scientific information. Such knowledge can best be acquired through co.ordinated research in hasic biological science on an international scale. Problems requiring such an international approach have arisen chiefly through the sudden changes in his environment, which man has produced in recent years, as well as the spectacular growth of human populations and the advance of civilization. They include: man's catastrophic transformation of natural communities of living organisms which often has greatly reduced their productivity; the need for increasing greatly the productivity of living com. munities all over the world to keep up with the world's growing population; the physiological stresses to which people are exposed because of their rapidlychanging ways of life; and the changes in genetic constitution of human populations caused partly by the rapid advance of civilization.

As an aid to solving these problems, the Planning Committee outlined a series of interrelated projects. for each of which a detailed programme of research will be prepared by a small sub-committee of scientists selected by the Planning Committee. Under the general title of "The Biological Basis of Productivity and Human Welfare", the following specific projects will be organized. Three projects will deal with the subject: "Biological Productivity of Terrestrial Communities". The first will devote its efforts to a general survey of terrestrial communities. The second will study the metabolism of terrestrial communities, particularly photosynthesis, the nitrogencycle, and the physiological interrelationships between organisms. A third project on terrestrial communities will seek methods of conserving them and increasing their productivity.

In addition to the projects concentrating on the land. one project will be devoted to fresh-water communities, and another to the biological resources of marine communities.

A group of human biologists, consisting of physiologists and geneticists working in collaboration with each other, will investigate the biological basis of human adaptability, both physiological and genetical.

The size and scope of these projects. as well as their duration, will be worked out by the sub-com. mittees. which are now being appointed by the Planning Committee.

Prof. G. Montalenti (University of Rome), convenor of the Planning Committee, expressed great satisfaction with the outcome of the conference. He an. 